(C) 2017

L. Novakovskyi, Academician of the National Academy of Sciences of Ukraine, Doctor of Economic Sciences

National Academy of Agrarian Sciences of Ukraine

Novakovska, Doctor of Economics

National Aviation University

\title{
ECOLOGICAL AND LEGAL PROBLEMS OF PROTECTION OF LANDS
}

The purpose. To determine modern lines of quantitative and qualitative changes in land-resource potential, directions, legal premises and volumes of land-protection operations. Methods. Analysis, synthesis, system of generalization, calculationalternative, prediction. Results. Features of work on protection of lands in pre-reform and after-reform periods are considered. Methodological approaches are justified concerning prediction of content of ecologically stabilized lands by application of indexes of edaphic features. That will stipulate necessity of rust-preventive treatment of lands. Legal statuses of formation of the act on this question are offered.

Directions are offered of perfecting control over land-use and soil fertility.

Conclusions. It is necessary to transmit control over protection of lands to the Ministry of agrarian policy and food, and to create the specific structural organ in its structure. It is also necessary to integrate scientific, design, agrochemicaland-passport and monitoring operations on the basis of use of the newest laboratories and materials of remote sensing of lands.

Key words: protection of lands, diagnostic study of soils, prognostic balance, stabilization, land-use, productivity, soils.

Conclusions Most of the Ukrainian lands are in pre-crisis, and sometimes in crisis conditions, with a tendency towards a progressive deterioration. Saving, efficient and ecologically safe use of the land resource potential of the country and its protection in modern conditions is one of the most urgent problems of national security of the country. The pre-crisis and crisis conditions of protection of land were not formed in the post-reform period (after 1991), but have a more ancient history. They are caused by excessive tillage of the land fund, the imperfection of agricultural systems, ignoring agronomic and environmental land use standards, the lack of proper land management system and soil fertility processes.

For 1961-2015, for example, the area of eroded arable land increased from 8 to 10.6 million hectares or 1.3 times. Worn arable land accounts for $32 \%$ of the area of arable land, and arable land exposed to wind erosion has reached an area of over 6 million hectares. It is water erosion and deflation (wind erosion) that directly threatens the existence of the soil, especially our black earths. Other qualitative soil characteristics (acidity, solosiness, salinity, technogenic contamination) deteriorate also. Issues of land conservation, in particular humus preservation, the fight against soil erosion, optimization of natural systems, etc. sufficiently investigated by domestic and foreign scholars [1, 2, 8, 15]. However, the insignificance of the state policy on the protection of soils and the removal of state from the financing of land 
protection measures for budgetary funds holds back the processes of protecting our soils.

Due to the fact that since 1980 there is not a large-scale survey of the whole area of land, and they, according to the law, should be carried out in 2020 for the third time, there is no updated information on the soil cover, neglected soil monitoring, not land-based land protection documentation was developed.

The purpose of the research is to determine the current trends in the dynamics of quantitative and qualitative changes in land-resource potential and trends, legal preconditions and volumes of land-protection works.

Research methods - analysis, synthesis, generalization system, calculation-variant, forecasting.

Research results. During the years 1957 - 1961 in Ukraine, for the first time a solid, large-scale soil survey was conducted. Mapping maps of scale from 1: 25000 to 1000000 have been drawn up, measures for rational use of lands and land resources protection have been developed for each agricultural enterprise. The development of projects and the implementation of anti-erosion works with the adherence to the principle of complexity of measures was initiated [15]. The General scheme of anti-erosion measures, similar schemes in each oblast, regional schemes has been developed. and working projects of anti-erosion measures within the limits of Norinsk, Siversky-Donetsk, Rzhyshivsk and other spur-beam systems. In the projects of agricultural land management and working projects of agro-technical, forest-meadow, hydrotechnical measures and structures, the main attention was paid to the principle of territoriality, that is, the simultaneous coverage of measures of entire hydrographic basins, spatial-beam systems, areas of wind erosion. Schemes for the implementation of anti-erosion measures have been developed in more than 50 regions with coverage of more than 9 million ha of territory [14]. In the 80 years, about 8 million hectares of land were drafted with land planning and contouringreclamation organization of the territory. Scientific developments of scientists of the Academy on this issue were noted in 1993 by the State Prize of Ukraine in the field of science and technology. There are still no alternatives to the contouringreclamation system of agriculture.

During the 1960 and 1990, measures were taken to increase the area of forests and protective forests, especially forest bands, due to the afforestation of ravines, steep slopes, gullies, banks of rivers, and others. the implementation of a complex of antierosion measures led to a reduction in the plow of land from 59.9 to $55.6 \%$, a significant increase in the area of forests and protective forests (by 2.8\%), an increase in the land of the water fund by $1.3 \%[13,9]$. Despite a slight reduction in the area of meadows and pastures (by 295.2 thousand hectares or by $0.5 \%$ ), the area of ecologically stabilizing landscapes has increased from 31 to $34.7 \%$ of the entire territory of the country. As evidenced by the dynamics of changes in the area of mainland during 1991 - 2016 (Table 1), the process of optimization of natural complexes continued in the post-reform period.

It should be noted that during the last 25 years the area of stabilizing landscapes increased from $34.7 \%$ to $38.8 \%$ (by $4.1 \%$ ), and for the entire 56-year period (1960 2016) - by $7.8 \%$. The area of arable land in 1960 - 2016 decreased by 1829,7 thousand hectares. 
The use of the main wealth - the land - should be based on the stabilization of land use by optimizing the natural components, the introduction of adaptive farming systems and the newest technologies for the implementation of high biological potential of modern varieties of crops [8].

Some scientists emphasize that the basis of stabilization of land use is the restoration of the broken relationship between natural complexes - the areas of grasslands, forests, water and crops. According to their calculations, the area of arable land in the state should be reduced by a minimum of 10 million hectares, transferring this area to natural forage lands and under flood protection [7]. Then the land under forest vegetation will occupy 18.1 million hectares or $30 \%$ of the territory of Ukraine (it will meet European standards), and the arable land will amount to 22.5 million hectares (the plow of the territory will decrease from 53.9 to $37.3 \%$ ).

Is it really By 1991, as is known, the arable lands of Ukraine were in state ownership. They were used by agricultural enterprises as large arrays. If there is an appropriate state program and funds from the state budget, the conversion of part of the arable land into natural forage and afforestation could be carried out more quickly. However, no program, no concrete projects, nor funds from the state budget for work on the transformation of arable land in such sizes were not provided. Not generally supported in the scientific environment and such a reduction in the size of the arable land.

Nowadays, when more than $84 \%$ of all arable land in the country is privately owned, this proposal is impracticable at all. If 10 million hectares had to be converted into afforestation and forage areas of 8 million hectares of arable land of private property and 2 million state-owned, then the compensation costs to land owners would be 275 billion UAH (at the rate of 40 thousand UAH per hectare for afforestation and 15 thousand UAH per 1 ha - for transformation in forage lands). For the national budget this is an unacceptable amount. It should also be borne in mind that the level of optimal woodiness, which is proposed - $30 \%$, far exceeds the calculations of many scientists - foresters and environmentalists (16.5 - 22\%) [14, p. 72, 73].

The draft National Program for the Use and Protection of Land submitted by the Cabinet of Ministers of Ukraine in 2004 for approval by the Verkhovna Rada of Ukraine supposed to reduce the area of arable land to 29.3 million hectares (48.5\% of the total land area), and the area of the forestry area the purpose to increase to 11.1 million hectares (18.4\%) [5].

The reality of these proposals is more likely, but this Program has not been approved and has not been implemented. Actual figures for areas in 2015 were: arable land 32.5 million hectares, which is more than $11 \%$ of the forecast, and forests and others afforestation - by $9.5 \%$ less than the forecasted level.

In 2000, the UAAS Institute of Land Management proposed criteria for determining the necessity of conservation of lands, which are based on the consideration of soil properties, whose grain values are established [12]. On their basis, the State Committee for Land Resources of Ukraine in 2002 approved the Procedure for Conservation of Land under Natural and Agricultural Zones (Order of the State Committee for Land Resources of October 17, 2002, No. 175).

The Ministry of Agrarian Policy and Food of Ukraine by an order dated April 26, 2013 approved a new Land Conservation Procedure, which is in force nowadays with amendments made to it in accordance with the orders of the Ministry of Agrarian 
Policy of Ukraine dated June 30, 2016, No. 219 and No. 7 January 7, 2017 No. 112) [17]. The list of properties and features of soils, separate units of the list of properties and features of soils, separate units of measure and indicators of soil properties (taking into account the zonal location) has been specified. In comparison with the previously proposed scientists of the Institute of Land Management, the criteria (2000) from the composition of properties and characteristics of soils exclude "carbonate" and additionally included "the action of organic soils (peat), as well as marsh and secondary flood". The remaining 12 indicators remained unchanged. The "carbonate content,\% of the weight of the soil" is excluded from the list of measuring units and includes "organogenic layer capacity, $\mathrm{cm}$ ", "groundwater level, m", "density of contamination by strontium-90, Ki / km2".

A number of changes were made in the size of indicators of soil properties, in particular: the content of physical soil clay of the light granulometric composition of the Polissya zone (as a percentage) was reduced from 5 to 3; Forest-steppe - from 10 to 7; Steppe and Dry Steppe - from 20 to 10. This same indicator for soils of heavy granulometric composition is set at the level of more than $50 \%$ for all zones (earlier it was proposed to set its value for non-forest rocks more than $60 \%$, and for rocks more than $75 \%)$.

The soil humus characteristics (\% of the weight of the soil) are reduced - from "less than 0.6 to less than 0.5 " from the weight of the soil, with "less 0.6 to less than 0.5 "in Polissya; with "less than 1.5 to less than 1.0" - in the forest-steppe, the northern and southern steppes, as well as "from less than 2.0 to 1.0" in the dry steppe.

The salinity level (as\% of the soil weight, in terms of toxic salts), which was more than 0.4 differentiated, is now established: for soda - more than 0.1 , for sulfatechloride - more than 0.2, for sulfate - more than 1.0.

Excess of maximum permissible concentrations of moving forms (ammonium acetate extraction), regardless of its level, is accepted as a sign of chemical contamination (earlier this excess was recommended at a level higher than 4 times the norm).

The density of pollution of the area by cesium-137 is left at the same level (more than $15 \mathrm{Ki} / \mathrm{km} 2$ ), and strontium-90 - approved at the level of more than $3 \mathrm{Ki} / \mathrm{Km}^{2}$. Consequently, the proposals of the scientists of the Institute of Land Management, both in terms of soil and in terms of soil properties, which determine the necessity of conservation of land, were tolerated as a whole by time verification and accepted as a basis for the approval of the relevant indicators. "Estimated indicators characterizing the soil properties and causing the need for conservation of land by natural and agricultural zones "[17]. According to the indicators of soil properties, the area of degraded, unproductive and contaminated arable land that needs conservation is 5.1 million hectares, of which $54.3 \%$ are washed and deflated, $11.5 \%$ are permeated and waterlogged, 9\% are saline soils [12]. From this total area of 2.7 million hectares is recommended to be planted. Under this option, the area of arable land will be 27.4 million hectares (45.4\% of the plow), and the area of forests and protective forests will be 13.3 million hectares (22\% of the forest cover). The comparison of the ratio of arable land and forests to the varieties suggests that their forecast for 2030, based on indicators of soil degradation, the size of unproductive lands and technogenic contamination of the areas, can be considered the most reasonable (Table 2). At the same time, the economic indicators (loss-making) of production of production on 
such lands are taken into account to a sufficient extent. By the availability of appropriate national and regional conservation programs, funds in the state and local budgets, after resolving a number of organizational and legal problems one could solve one of the fundamental basic issues of environmental protection and soil conservation - to ensure optimal correlation of land.

Despite the fact that the new Land Code of Ukraine came into force on January 1, 2002, the legislative act, which would establish the procedure for conservation of land, has not yet been developed. The legal provisions for the conservation of land, as defined in the Land Code and the Law of Ukraine "On Land Conservation", are a state-of-the-art national law but regulate only certain provisions of its implementation. The procedure for the use and protection of technogenically polluted land also does not exist. No standards have been developed in the field of land conservation and reproduction of soil fertility, the adoption of which is envisaged by Article 165 of the Code [6].

By law, conservation of land should be carried out by a decision of the executive authorities and local self-government bodies on the basis of agreements with land owners. However, contractual relations in this regard should be foreseen for land users (with constant use and in case of lease). The Law "On the Procedure of Conservation of Land" should also regulate other issues, in particular: a) clearly determine the procedure for funding land conservation measures at the expense of the state and local budgets, the owners of land and land users associated with conservation, compensation for the reduction of income due to temporary conservation, reduction of productivity of land, stimulation of regulation of land at their own expense; b) establish that land conservation is carried out not only on the initiative of land owners and land users, but primarily on the basis of the submission of executive bodies and local governments that control the use and protection of land, as well as monitoring of land resources and soils; c) to guarantee the land and property rights of owners and land users during the conservation, obtaining, if possible, of other equivalent land plots instead of those that are preserved (transformed), or the cost of land in cash; d) to improve the mechanism of conservation, excluding elements of coercion at the initiation of works, to clearly establish the rights and obligations of participants in the conservation process. In the field of land conservation and reproduction of soil fertility, the law provides for the establishment of the following norms: the optimal ratio of land; qualitative state of soils; maximum permissible contamination of soils; indicators of land degradation and soils. Most standards and norms have not yet been developed. This holds back the work on specific conservation measures for soil fertility, prevents compilation of grounded documentation for implementation of these measures.

In order to implement the National Action Plan on combating land degradation and desertification, approved by the Cabinet of Ministers on March 30, 2016, a draft Quality of Soil Regulations was recently published. The norms include indicators and parameters of the structure, composition and properties of soils, characterizing the level of contamination, the optimal content of nutrients, physical and chemical properties, etc., in which the soil retains the ability to perform its productive, ecological and social functions [18].

To determine the parameters of the indicators, data from agro-chemical certification of agricultural land and land monitoring are used. It is proposed to change the 
indicators by comparing past and present values of land certification and monitoring. The deterioration of soil quality and deterioration of their fertility should be considered dangerous if the numerical values are reduced by at least two parameters, namely: reduction of humus content in the soil by more than 5\%; reduction in the content of mobile phosphorus compounds in the soil (mg / $\mathrm{kg}$ of soil) by $15 \%$ or more; reduction in the content of potassium mobile compounds in the soil (mg / kg of soil) by $15 \%$ or more; reduction of $\mathrm{pH}$ of salts on acid soils by $10 \%$ or more; increase of $\mathrm{pH}$ of water in alkaline soils by $10 \%$ or more; increase in the content of absorbed sodium by more than $5 \%$ from the absorption capacity of the soil; Increase salinity by 1 degree or more.

Indicators of soil properties, which determine the conservation of land, should be clarified after the approval of the norms of the qualitative state of land and the maximum permissible soil contamination.

The soil condition has largely lost its function of self-regulation. Water and wind erosion are directly threatened by the soil. Actions of water erosion are subject to 13.3 million hectares (32\%) of agricultural land, the wind - more than 6 , and dust storms - to 20 million hectares.

The use of mineral fertilizers decreased from $148 \mathrm{~kg}$ of active substance per hectare in 1986 - 1990 to $76 \mathrm{~kg}$ in 2011-2015, organic - from 9.4 to 0.5 tonnes per hectare. Between 1986 and 1990, the balance of nutrient elements in agriculture was positive (the input of elements in the soil exceeded the cost of $21.3 \mathrm{~kg}$ of NPK per hectare). Due to the measures taken, it was possible to reach the harvest of grain at the level of 50 million tons. For 2011-2015, the balance of nutrient elements was negative and amounted to $47.4 \mathrm{~kg}$ of active substance NPK per hectare (figure).

The content of humus has decreased over the past 20 years by $0.22 \%$ in absolute terms, although for an increase of its level by $0.1 \%$ under natural conditions it takes 25 - 30 years. Crop rotation has been violated. In some areas sunflower takes up to $30 \%$ of arable land and returns to the previous field in 3 years instead of the recommended period - 6 - 7 years.

A significant number of problems in land use is connected with the implementation of land reform in the country. Negative consequences of market conditions, market utilization of land, generalization and irresponsibility of land users have increased especially in recent times. The fundamental task of the reform - ensuring rational use and protection of land is implemented extremely slowly. Privatization of agricultural land under the moratorium on purchase and sale land plots makes it impossible to have a real owner - the owner of the land [11].

Consolidation of land, which was divided into land parcels, is not carried out. Almost 1.4 million hectares of decomposable land plots are not used. About 1,0 million people do not process or rent land, therefore, almost 5 million hectares or about $12 \%$ of the total area of agricultural land is not used. The only type of land tenure of small owners in the village is the transfer of land to rent. At the same time, the average rent amount remains rather low (1093 UAH per hectare), and much of the leased land loses its fertility due to non-compliance with agronomic and ecological requirements of management [4].

Work on protecting the land fund of the country at the state level is abandoned, national programs of land use and reproduction, soil fertility protection, land conservation law has not yet been developed. The state budget does not provide 
funds for land-security measures and increase of soil fertility, although almost half of the total land area is in state ownership. The activities of a number of central executive bodies are still focused only on carrying out work on the provision of the necessary information to the state land cadastre, the organization of the provision of agricultural land of state-owned land for lease at auctions, the transfer of land plots to the ownership and use of ATO participants. It is inadmissible to cease work on the development of land-use documentation related to the protection of the soil cover of the country.

In this regard, the adoption by the Cabinet of Ministers of Ukraine of the Resolution of the Cabinet of Ministers of June 7, 2017 No. 413 "Some Issues of Improvement of Management in the Use and Protection of Agricultural Land Purposes of State Owned Land and Disposal" was very timely and relevant [4].

The main objectives of the Strategy for Improving the Management Mechanism in the Field of Use and Protection of Agricultural Land of State Owned Property and their disposal, approved by the said decree, are the following:

- Implementation of the principles of strategic management in the management system in the field of use and protection of these lands;

- Ensuring optimal use of land, in particular taking into account regional programs and plans for the development of territories, general plans of settlements;

- Increasing the level of transparency and publicity during the formation and implementation of state land policy;

- Increasing awareness of the population, landowners and land users about land degradation and sustainable land use;

- Prevention of soil degradation processes, increase of soil fertility level.

The Cabinet of Ministers of Ukraine put in place the implementation of the approved Strategy on the Ministry of Agrarian Policy and the State Audit Office in accordance with the powers of the said central bodies of executive power as defined by the legislation. To implement the Strategy, it is envisaged to develop projects in 9 key areas for improvement of land use management, most of which are strategic. The indicated Strategy, however, is short-term and it can not replace the National Program for the Use and Protection of Land, which should be approved by the Law of Ukraine, as well as the State Program for the Protection of Soil Fertility, which was supposed to have under the Law on Land Conservation.

The aging of information on the state of the soil that prevents land from degrading prevents the efficient use of land. Due to the departmental mismatch of monitoring observations, this information is not consistent with each other, is limited and almost inaccessible for use not only by the supervisory authorities, but also for citizens. The system for monitoring the use and protection of land should be based primarily on monitoring information.

The Presidium of NAAS, with the support of the Ministry of Agrarian Policy of Ukraine, proposed the identification of the National Science Center "Institute Soil Science and Agrochemistry named after O.N. Sokolovsky "interdepartmental national soil and information center of Ukraine. The specified center should contain a national archive of soil data, a special portal with advisory and educational functions, a system of exchange of ground information with national and foreign users. The organization of information support for monitoring of soils, the construction and publication of materials on the state of soil cover and priority 
measures for its protection is proposed to be placed at the specified center.

Consequently, by creating a ground information center, we will be able to unite the information on the soil cover, the state of its use and degradation scattered at the departments nowadays, and on this basis to organize ecologically safe land use and protection of land resources.

But it is extremely important to have reliable soil information. The land monitoring regulations have been in place since August 1993. The Land Conservation Act has been in force since June 2003. However, the completed land monitoring system has not yet been established. Measures to combat soil degradation are not foreseen in the state budget. The current system of organization of land management and soil fertility is also imperfect.

According to the Land Code of Ukraine, in the wording of March 13, 1992, when collective and private land ownership was introduced, the development and implementation, along with rayon and city councils of deputies of oblast programs on rational land use, soil fertility, land protection attributed to the jurisdiction of regional councils of people's deputies. Development and implementation together with the AR of Crimea, local councils of state programs on rational land use, soil fertility improvement, protection of land resources in combination with other environmental protection measures is determined by the competence of the Cabinet of Ministers of Ukraine [10].

With the adoption on 25 October 2001 of the current Land Code, the situation regarding the regulation and implementation of land protection has changed substantially:

- The powers of the Verkhovna Rada of Ukraine approval of national programs on the use and protection of land;

- The development and implementation of national programs for the use and protection of land is determined by the powers of the Cabinet of Ministers of Ukraine;

- The approval of national programs for the use and protection of land and the approval of regional programs and the participation in their implementation are attributed to the powers of the regional councils;

- The central executive body on ecology and natural resources has one of its powers to participate in the development and implementation of national and regional programs for the use and protection of land, the organization of land monitoring; - A similar authority, ie participation in the development and implementation, has a central executive body on land resources.

Consequently, the Cabinet of Ministers ensures implementation, and the two central executive authorities (the Ministry of Environment and the State Committee for Land Resources) are involved in the implementation of land-protection programs.

In 2010, the central executive authorities of the country were divided into those that form the state policy in the relevant sector or sphere, and those that implement the policy.

In the field of land relations, the bodies responsible for the formation of this policy have become the Ministry of Environment and the Ministry of Agrarian Policy, and the bodies that implement it are the State Committee on Civil Aviation, the State Inspection and the State Inspection in the sphere of state supervision (control), which has actually been abolished. If we proceed from the powers established in the current 
Code for Mine and Resource Management and Ministry of Agrarian Policy, then the Ministry of the Environment is involved in the development of national and regional programs for the use and protection of land, in the formation of state policy in the field of protection and rational land use, and organizes land monitoring (Article 14 Code), and the Ministry of Agrarian Policy - ensures the formation of state policy in the field of land relations, in particular land reform, develops and ensures the implementation of national, ehionalnyh use and protection programs lands, ensures the protection of land and the reform of land relations (Article 15 of the Code). Consequently, under the legislation, the Ministry of Agrarian Policy and Food formulates land-security policy, develops and ensures the implementation of land protection programs of the country, that is, it is the main function of the indicated functions.

In the absence of approved national and regional programs for the protection of land and soils, approval by the Cabinet of Ministers of the Concept of Combating Land Degradation and Desertification for 2015-2020 in October 2014 [19], as well as adoption in March 2016, is important. National Action Plan for the implementation of this Concept. The action plan contains 42 tasks, it specifies the specific organizers and performers of works and the terms of their implementation. The management of the implementation of the action plan is entrusted to the Ministry of Environmental Protection. The measures envisaged for implementation in 2016-2017, as the analysis shows, has not yet been implemented. This concerns bills on soil conservation and the protection of their fertility, a number of draft resolutions of the Government.

The issue is not solved and the issue of conducting solid ground surveys, which is scheduled to be carried out during 2016-2020. They did not start in 2016, this year they are not conducted, and by 2018 in the draft state budget of the country the funds for the implementation of these works are also not provided.

Under the law, repeated ground surveys should be conducted after 20 years. In the 70's and 80's of the twentieth century. an adjustment was made parts of soil science materials and found that the soil cover has undergone significant changes. It is impossible to estimate the actual state of soil resources without conducting a solid study of soils. Expert calculations show that modern soil information corresponds to reality by $50 \%$, and in zones with complex soil cover - by $35 \%$.

According to the Action Plan on combating degradation and desertification, the Ministry of Agrarian Policy and Food, the Oblast State Administration and the National Academy of Agrarian Sciences of Ukraine are responsible for conducting soil surveys in 2016-2020. In the draft budget for the coming year, the specified ministry is expected to allocate 77 million USD for all research, applied scientific and technical development, implementation of state target programs. Oblast state administrations and NAAS also do not have funds for this. Consequently, this task of the National Action Plan will be disrupted.

The Ministry of Agrarian Policy and Food is not able to perform land protection functions without establishing a structural unit of the central unit (Department or Directorate), consolidating the efforts of scientific, project organizations, agricultural bodies and the public to protect our chernozem. We can not do without the creation of the Innovative Fund for Land Conservation, as the budget funds for the protection of the main national wealth - land - is not allocated. 


\section{Conclusions}

The measures taken to optimize the structure of land and stabilize agricultural landscapes during the last decades have led to a partial decrease in the level of cultivation of the territory from 59.9 to $53.9 \%$, as well as an increase in forest cover from 14.1 to $17.6 \%$. Further measures to optimize the structure of the land should be based on soil indicators, which determine the need for conservation of land and take into account the level of profitability of production in these lands.

Restoration of the energy potential of the soil is impossible without stabilizing the level of humus. The introduction of the necessary standards for organic and mineral fertilizers, the revision of the structure of crops with the reduction of the share of export-oriented crops, the cessation of soil degradation processes remain the main factors of soil conservation for future generations. Chain - large farms $\rightarrow$ soils without organic fertilizers $\rightarrow$ fertility, borrowed from our children and grandchildren - has no prospect of the future.

"The people who destroy their soil - destroys themselves" - Franklin D. Roosevelt.

\section{Bibliography}

1. Balyuk S.A. Suchasni problemy biolohichnoyi dehradatsiyi chornozemiv i sposoby zberezhennya yikh rodyuchosti/S.A. Balyuk, B.S. Nosko, Ye.V. Skryl'nyk//Visn. ahrar. nauky. — 2016. — № 1. - S. $11-17$.

2. Bulyhin S.Yu. Formuvannya ekolohichno stalykh ahrolandshaftiv: navch. posib./S.Yu. Bulyhin. — Kh.: Vyd-vo KhDAU, 2001. — 118 s.

3. Derzhavnyy zemel'nyy kadastr Ukrayiny za stanom na 1 sichnya 1996 roku. Kn. II . - K.: Derzhkomzem Ukrayiny, 1986. - $172 \mathrm{~s}$.

4. Deyaki pytannya udoskonalennya upravlinnyav sferi vykorystannya ta okhorony zemel' sil's'kohospodars'koho pryznachennya derzhavnoyi vlasnosti ta rozporyadzhennya nymy: Postanova Kabinetu Ministriv Ukrayiny vid 7 chervnya 2017 r. № 413//Uryadovyy portal. URL:

http://www.kmu.gov.ua/control/uk/cardnpd?docid=250068882

5. Zahal'noderzhavna prohrama vykorystannya ta okhorony zemel'. Pasport Zahal'noderzhavnoyi prohramy vykorystannya ta okhorony zemel': Proekt Zakonu Ukrayiny. - Rezhym dostupu:

http://www.myland.org.ua/index.php?id=1532\&lang=uk

6. Zemel'nyy kodeks Ukrayiny vid 25.10. 2001 № 2768 - III /Baza danykh «Zakonodavstvo Ukrayiny»//VR Ukrayiny. URL:

http://zakon2.rada.gov.ua/laws/show/2768-14

7. Kamins'kyy V.F. Zdolaty real'nu zahrozu/V.F. Kamins'kyy//Ahrar. tyzhden'. — 2017. — № 8 - 9 (322).

8. Natsional'na prohrama okhorony gruntiv Ukrayiny: za red. S.A. Balyuka, V.V. Medvedyeva, M.M. Miroshnychenka. — Kh.: Smuhasta typohrafiya, 2015. — 60 s. 9. Novakovs'ka I.O. Metodolohichni aspekty zberezhennya osnovnoho natsional'noho bahat·stva/I.O. Novakovs'ka//Visn. ahrar. nauky. — 2017. — № 8. — S. 71 - 76. 10. Novakovs'ka I.O. Osnovy ekonomiky zemlekorystuvannya: monohr./I.O. Novakovs'ka. — K.: VTs «Prosvita», 2013. — 224 s.

11. Novakovs'ka I.O. Transformatsiya sil's'kohospodars'koho zemlekorystuvannya: monohr./I.O. Novakovs'ka. — Chernivtsi: Prut, 2010. — 208 s. 
12. Novakovs'kyy L.Ya. Konservatsiya dehradovanykh i maloproduktyvnykh ornykh zemel' Ukrayiny/L.Ya. Novakovs'kyy, O.P. Kanash, V.O. Leonets'//Visn. ahrar. nauky. — 2000. — № 11. - S. 54 - 59.

13. Novakovs'kyy L.Ya. Zemel'ni resursy Ukrayins'koyi RSR/L.Ya. Novakovs'kyy, M.A. Pylypenko. - K.: Urozhay, 1973. — 240 s.

14. Novakovskyy L.Ya. Эkonomycheskye problemы yspol'zovanyya y okhranы zemel'nыkh resursov/L.Ya. Novakovskyy. — K.: Vyshcha shk., 1985. — 208 s. 15. Pryroda Ukraynskoy SSR. Pochvы/N.B. Vernander, Y.N. Hoholev, D.Y. Kovalyshyn. - K.: Nauk. dumka, 1986. - 216 s.

16. Pro zatverdzhennya Natsional'noho planu diy shchodo borot'by z dehradatsiyeyu zemel' ta opustelyuvannyam: Rozporyadzhennya Kabinetu Ministriv Ukrayiny vid 30 bereznya 2016 r. № 271-r/Baza danykh «Zakonodavstvo Ukrayiny»//VR Ukrayiny. URL: http://zakon0.rada.gov.ua/laws/show/271-2016-\%D1\%80 17. Pro zatverdzhennya Poryadku konservatsiyi zemel': Nakaz Ministerstva ahrarnoyi polityky ta prodovol'stva Ukrayiny vid 26 kvitnya 2013 r. № 283/Baza danykh «Zakonodavstvo Ukrayiny»//VR Ukrayiny. URL:

http://zakon3.rada.gov.ua/laws/show/z0810-13

18. Pro normatyvy yakisnoho stanu gruntiv:

Proekt Postanovy Kabinetu Ministriv Ukrayiny/Ministerstvo ahrarnoyi polityky ta prodovol'stva Ukrayiny. URL: http://minagro.gov.ua/node/22918

19. Pro skhvalennya Kontseptsiyi borot'by z dehradatsiyeyu zemel' ta opustelyuvannyam: Postanova Kabinetu Ministriv Ukrayiny vid 22 zhovtnya 2014 r. № 1024-r/Baza danykh «Zakonodavstvo Ukrayiny»//VR Ukrayiny. URL: http://zakon0.rada.gov.ua/laws/show/1024-2014-\%D1\%80 